\title{
Tierra y trabajo en las haciendas de cofradías indígenas de Yucatán, siglo XVIII
}

\author{
Gabriela Solís Robleda
}

El estudio de las haciendas vinculadas a las cofradías, que se crearon y fomentaron en los pueblos mayas, nos brinda una imagen de la complejidad de la sociedad que las produjo. Estas haciendas fueron proyectos corporativos promovidos por la dirigencia indígena. La información sobre estas empresas permite postular que la élite nativa mantuvo una de sus principales funciones, que era la de dirigir y organizar el esfuerzo colectivo, al mismo tiempo que evidencia su capacidad de adaptación a las condiciones impuestas. Se analizan dos variables: la tenencia de la tierra y la organización laboral. El caso de esta tenencia es complejo pues coexiste con las tierras comunales, las corporativas y las privadas y con una estrategia que reforzó la propiedad corporativa. En lo que respecta a la cuestión laboral, es posible observar que distintas formas de acceso al trabajo fueron utilizadas por quienes administraban estas unidades productivas, ya sea continuando los mecanismos propios como adaptando aquéllos impuestos, pues se consignaron tanto el trabajo colectivo y el asalariado como el de comisionados por el cabildo, el de servidores de iglesia y el de luneros.

The study of haciendas related to cofradías, which were created and promoted in Mayan villages, presents us with an image of the complexity of the society that produced them. These haciendas were corporate projects promoted by the indigenous ruling class. The information on these enterprises allows us to affirm that the native elite kept one of its main functions, that is: to direct and organize the collective effort and at the same time it shows their capacity to adapt to the conditions imposed. Two variables are analyzed: land tenure and organization of labor. The case of tenure is complex as communal land coexisted with corporate and private land and with a strategy which reinforced corporate property. Regarding the labor issue, one can observe that different forms of access to work were used by those who administered these productive units, either by continuing their own mechanisms or by adapting those imposed for it covered collective work, paid work and that commissioned by the town council, by Church officers or by luneros.

GABRIELA SOLÍ́s RoBledA: CIESAS-Programa Peninsular.

Desacatos, núm. 13, invierno 2003, pp. 13-31. 
$\mathrm{E}$ n el análisis de la sociedad maya yucateca subyacen distintas propuestas de interpretación que han optado por privilegiar una forma de organización más igualitaria o por asignarle a la estratificación interna un papel determinante para definir las relaciones sociales. Esta discusión se enmarca en una polémica más extensa que ha girado alrededor de la caracterización de los pueblos indígenas mesoamericanos, especialmente para el centro de México. A mediados del siglo pasado se difundió la propuesta para el México antiguo de Paul Kirchhoff sobre la coexistencia de una organización tribal clánica organizada en calpullis que se habría subordinado a una forma más compleja de organización basada en la propiedad y con características clasistas. ${ }^{1}$ Esta propuesta abrió el camino para la generación de importantes trabajos sobre la organización social indígena prehispánica y colonial que han destacado la relevancia de la "casa señorial", y por tanto, de la estratificación, en la caracterización de las formaciones sociales indígenas. Asimismo, se han cuestionado las premisas que llevaron en el siglo XIX a postular al calpulli como un sistema igualitario. ${ }^{2}$ El problema de la estratificación interna también ha sido abordado en los estudios modernos de las llamadas comunidades indígenas. ${ }^{3}$

En estudios anteriores hemos planteado que los mayas construyeron una sociedad marcada por una clara y tajante división entre principales y macehuales, cuyos papeles se definían por relaciones de dominio y sujeción en el marco de una estructura corporativa, y que la posibilidad de la sociedad maya de multiplicar los esfuerzos individuales estuvo asociada a una clara estratificación donde un reducido grupo tenía el dominio de la mayoría de la

\footnotetext{
${ }^{1}$ P. Kirchhoff, "Land Tenure in Ancient Mexico...", 1954-1955, pp. 359-360.

${ }^{2}$ En esta línea que analiza la organización social destacan las aportaciones de P. Carrasco, J. Broda, L. Reyes y H. Martínez.

${ }^{3}$ En su propuesta de comunidades campesinas corporadas cerradas, Eric Wolf asigna su origen en la situación colonial, pues supone que las presiones económicas aceleraron las tendencias hacia una mayor igualdad y nivelación entre la población indígena. E. Wolf, "Closed Corporate Peasant Communities", 1957, pp. 11-12. El propio Wolf reconocería que su perspectiva histórica resultaba esquemática y que estudios contemporáneos mostraban, por ejemplo, que el sistema de cargos sí redistribuía el excedente pero no nivelaba las diferencias de clase. E. Wolf, "The Vicissitudes of the Close Corporate Peasant Community", 1986, pp. 326-327.
}

población. ${ }^{4}$ Un conjunto de elementos controlados por este pequeño grupo les permitía conseguir y mantener el liderazgo social, entre los que destaca el manejo del conocimiento especializado y de la vida ritual, el control del uso de la tierra, ${ }^{5}$ las restricciones impuestas para tener acceso al ejercicio del poder y la organización de empresas corporativas. ${ }^{6}$ Este último elemento se manifestó claramente, con la imposición del sistema colonial, en la creación y fomento de haciendas vinculadas a las cofradías que se crearon y desarrollaron en los pueblos mayas. Al ser la cofradía una institución de origen europeo, su análisis puede ofrecer indicios de la manera cómo la élite indígena mantuvo una de sus principales funciones, que era la de dirigir y organizar el esfuerzo colectivo, pero también evidencia su capacidad de adaptación a las condiciones impuestas.

Nancy Farriss ha señalado la importancia en Yucatán de las cofradías indígenas como empresas corporativas; las equipara a las cajas de comunidad al tener funciones civiles y religiosas comunes encaminadas a promover el bien común y asegurar la supervivencia de la comunidad. Por ello, las define como "una de las adaptaciones más brillantes del pueblo maya a la adversidad del régimen colonial". Sólo hace una breve referencia a la estratificación al señalar que el hecho de que las cofradías fueran una empresa colectiva no implicó que los mayas no reconociesen sus divisiones internas. ${ }^{7}$ Robert Patch, en cambio,

\footnotetext{
${ }^{4}$ Bracamonte y Solís, Espacios mayas de autonomía, 1996, cap. 2; y G. Solís Robleda, Bajo el signo de la compulsión, 2000, pp. 276-296.

${ }^{5}$ El análisis de la tenencia de la tierra es fundamental en la discusión sobre el grado de estratificación de las sociedades indígenas. En el apartado correspondiente se abordará brevemente la discusión entre la predominancia de propiedad comunal o privada.

${ }^{6}$ En un sentido amplio, entendemos por empresas corporativas aquellas acciones concertadas por la población indígena organizada en un esquema estratificado y de subordinación, donde la dirección recaía en un grupo determinado que controlaba el gobierno local. Este tipo de acciones estaba encaminado a conseguir diversos fines para la colectividad y afianzar los lazos entre la población subordinada y la élite.

${ }^{7}$ N. M. Farriss, La sociedad maya, 1992, pp. 287, 412, 414. Su referencia a la diferenciación interna se limita a señalar las diferencias en el pago de limosnas a la cofradía. Dagmar Bechtloff, en su estudio sobre las cofradías michoacanas, ha destacado también "la red de relaciones entre cofradías y comunidad", y que fueron instrumento de adaptación a las nuevas condiciones sociales, culturales, políticas y económicas, sobre todo en tiempos de crisis. Véase D. Bechtloff, Las cofradías en Michoacán, 1966, pp. 17-19.
} 


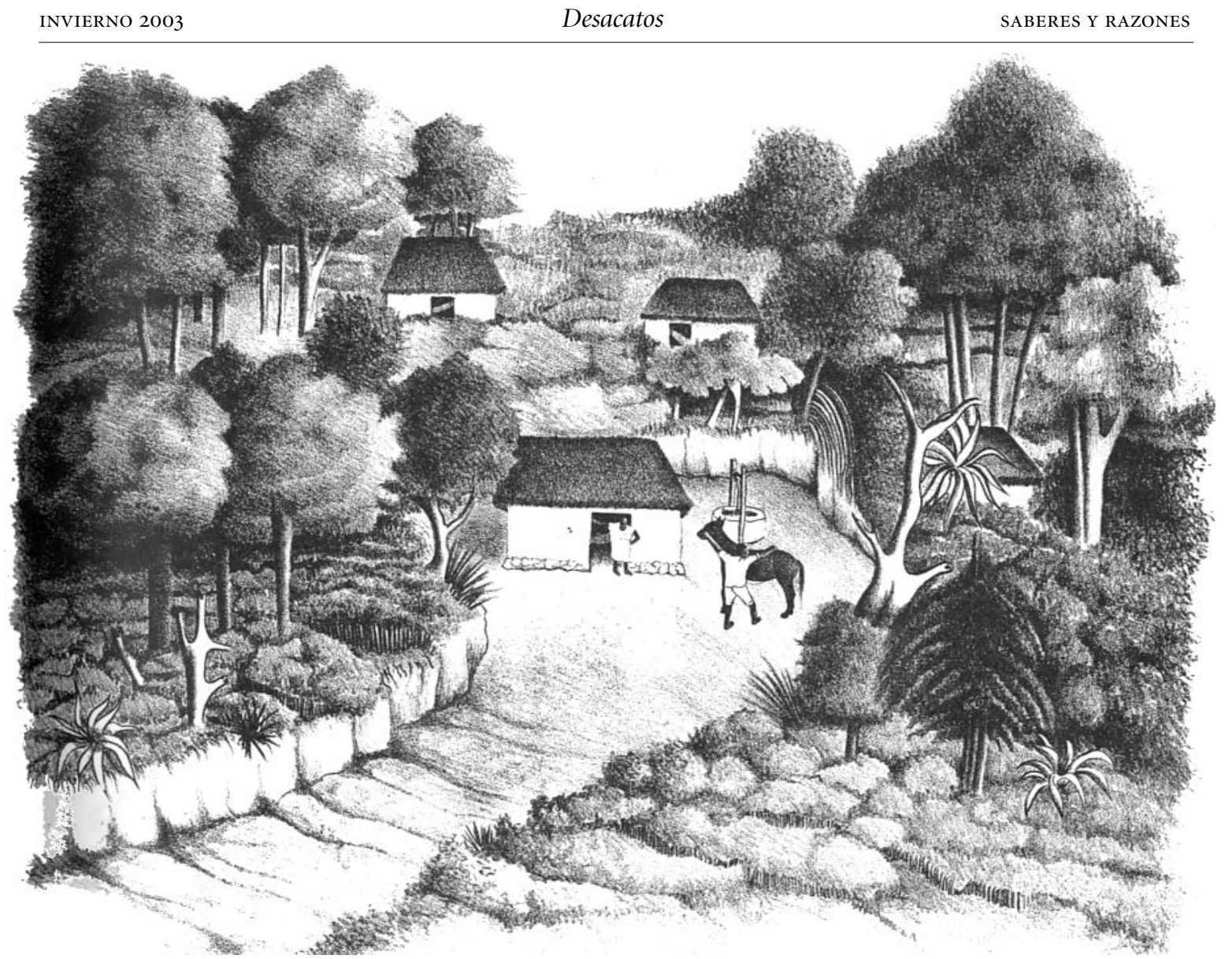

Francisco Dosamantes, Pueblo maya, 1942.

ha puesto énfasis en el papel de las cofradías para reforzar la estratificación interna de la sociedad maya pues, aunque los viejos sustentos de la estratificación social fueron eliminados, aparecieron nuevos y fueron tomados por las élites emergentes para preservar un orden social estratificado. Entre estos nuevos sustentos menciona en primer lugar a las cofradías, que ofrecieron a la clase dirigente la oportunidad de continuar sirviendo como líderes espirituales, del mismo modo que en la época pre-

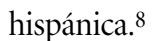

Matthew Restall recurre a la cofradía maya para ejemplificar la manera en la que los mayas vinculaban estrechamente lo religioso con lo social, lo político y lo

${ }^{8}$ Robert Patch, Maya and Spaniard in Yucatan, 1648-1812, 1993, p. 25. económico; de esta forma estaban mejor preparados para mantener una vida organizada independiente. La cofradía maya ilustra esta interrelación al ser un campo propicio para las políticas comunitarias y para la empresa económica colectiva, de índole económica más que religiosa en sus fines y en su concepción. Sin embargo, previene contra la separación analítica de esos ámbitos ya que puede conducir a soslayar que tanto el culto y el ritual religioso, como las actividades económicas de la cofradía, contribuyeron a mantener la cohesión del pueblo. ${ }^{9}$

No hay duda de que las distintas propuestas sobre el papel de la cofradía en la sociedad maya colonial coinciden en señalar su importancia como espacio que permitió

\footnotetext{
${ }_{9}^{9}$ M. Restall, The Maya World, 1997, p. 152.
} 
la expresión de la vida religiosa de los pueblos indígenas, a la par que brindó mecanismos para la generación de recursos económicos que fortalecieron el funcionamiento corporativo de las repúblicas de indios. Pero en estas líneas el análisis se centra en la red de relaciones que se tejieron alrededor de la tenencia de la tierra y la organización laboral de las haciendas vinculadas a las cofradías indígenas, al ser indicadores importantes para lograr una mejor comprensión del grado de estratificación de la sociedad maya yucateca colonial. En otras áreas de la América española, el análisis de la tierra y el trabajo ha sido determinante para profundizar el conocimiento de la sociedad global colonial. Los estudios apuntan a señalar que las unidades políticas prehispánicas se sustentaban en el control por parte del aparato de dominio de un binomio tierra/gente..$^{10}$ De aquí que se registre un énfasis por vincular el análisis de la tenencia de la tierra con la organización social. ${ }^{11}$ Mucha atención han recibido los cambios en lo que se refiere a la tenencia de la tierra indígena en la situación colonial. ${ }^{12}$ Los trabajos que privilegian la variable laboral fueron impulsados por los proyectos dirigidos por Ángel Palerm sobre la organización del trabajo indígena encauzado a las obras públicas estatales, de donde se derivó el interés por el análisis del trabajo en la época colonial. En esta nueva situación, el control de los macehuales se reorganizó utilizando mecanismos prehispánicos y creando instancias coloniales a través de las cuales se tenía acceso al trabajo mediante el control indirecto de la población. ${ }^{13}$

A partir de los documentos que generó la controversia sobre los remates de las haciendas de cofradías indígenas que llevó a cabo el obispo fray Luis de Piña y Mazo,

${ }^{10}$ Véase por ejemplo los trabajos de H. Martínez, Tepeaca en el siglo XVI..., 1984, y P. Carrasco, "La economía del México prehispánico", 1978.

11 Véase P. Kirchhoff, "Land Tenure in Ancient Mexico...", 1954-1955, y J. Lockhart, The Nahuas Alter the Conquest, 1992.

${ }^{12}$ Ch. Gibson, Los aztecas bajo el dominio español, 1980, cap. 10; H. Martínez, Codiciaban la tierra..., 1994; y C. S. Assadourian, Transiciones hacia el sistema colonial andino, 1994, cap. III.

${ }^{13}$ Véase T. Rojas Rabiela, "El trabajo de los indios en la ciudad de México: 1521-160o", 1987; Ch. Gibson, Los aztecas bajo el dominio español, 1980, cap. 9; W. L. Sherman, El trabajo forzoso en América Central en el siglo XVI, 1985; S. J. Stern, Peru's Indian Peoples and the Challenge of Spanish Conquest..., 1993, caps. 4-7. medida contra la cual se manifestó el gobernador Roberto Rivas Betancourt en 1782, se examinarán el origen y las variables de la tierra y el trabajo al interior de estas unidades productivas auspiciadas por los pueblos de indios de la provincia yucateca, dada su importancia como empresas corporativas para la sociedad maya colonial. ${ }^{14}$

\section{ORIGEN DE LAS HACIENDAS}

Las declaraciones de indios del año de $1782^{15}$ incluyen referencias sobre el origen y los fines de sus cofradías, así como sobre el destino de sus fondos, que indican que las haciendas que auspiciaron fueron proyectos corporativos promovidos por la dirigencia indígena como apoyo para afrontar las cargas que pesaban sobre los pueblos y para el socorro en épocas de hambrunas. Como diría Nancy Farriss: "para hacer frente a las desgracias gemelas de las peticiones de los españoles y las pérdidas de la cosecha".16 Este objetivo primordial se relacionaba estrechamente, a la vez que se encubría, con el culto. En la mayoría de los casos se consignó que el origen de las haciendas de cofradía de los pueblos indios había sido la junta o congregación de los principales, cacique y justicias, formalizada con escritos en maya de sus cabildos. Casi ninguna contó con las licencias necesarias para su existencia legal. ${ }^{17} \mathrm{En}$ contraste, muchas cofradías conservaban los instrumentos de fundación o de donación hechos sin intervención de los ministros del Tribunal de indios. ${ }^{18}$ Así por ejemplo, la cofradía de Mocochá no contaba con las licencias requeridas pues "solos los naturales de dicho pueblo hicieron

${ }^{14}$ La documentación consultada se encuentra en el Archivo General de Indias de Sevilla, expediente 3066, que consta de casi 1100 fojas.

${ }^{15}$ Estas declaraciones se registraron en AGI, México 3066, ff. 130r-923r.

${ }^{16}$ Nancy M. Farriss, La sociedad maya bajo el dominio colonial, 1992, p. 142.

${ }^{17}$ Esta situación se dio a pesar de los reiterados esfuerzos de las autoridades eclesiásticas por sancionar las cofradías, como el caso del Sínodo Diocesano de 1722 donde el obispo ordenó que no se erigiese cofradía alguna "sin nuestra especial y expresa licencia", ni tampoco se hiciesen constituciones ni estatutos sin ser examinados y aprobados. CAIHY, El Sínodo Diocesano, año de 1722, ff. 87v-89v.

${ }^{18}$ Según afirmó el cacique del pueblo de Chemax, "nunca proceden los indios con estas formalidades". AGI, México 3066, Declaración de Pascual Cauich, Valladolid a 9 de julio de 1782, ff. 829v-831v. 
unas constituciones bajo de cierta cantidad corta - según los posibles de cada cual— que daban por la entrada y una multa levísima por los que faltaban a los mandatos de la hermandad". Con esos recursos compraron diez novillonas que se pusieron en las tierras del pueblo. En el pueblo de Baca, su hacienda se fundó en tierras que un indio compró a otro y sus constituciones las hicieron únicamente el cacique y justicias de ese pueblo. ${ }^{19}$

Los indios declarantes insistieron en el hecho de que las fundaciones de haciendas de cofradía fueron una acción de la colectividad, bajo el control de la dirigencia nativa. Por ejemplo, en el caso de la hacienda del pueblo de Baca su cacique no podía "decir quienes fueron los primeros fundadores porque realmente fue todo su pueblo, entre pequeños y grandes, [...] dando cada individuo todas las semanas cinco granos de cacao de limosna”. Al cabo del año se vendió el cacao y con su producto se costeó una misa que el pueblo debía pagar anualmente; con el sobrante el cacique compró tierras, pozo y ganado vacuno para poblar la hacienda. ${ }^{20}$

Al fundar estas haciendas, la intención generalizada consistía en descargar al pueblo de al menos una parte de sus obligaciones, pues la corporación debía hacerse cargo del costo de misas, procesiones y sermones, de cera para los santos, de pólvora para las fiestas e incluso de espectáculos. Al fomentar las cofradías para solventar estas cargas, el pueblo quedaba en mejores condiciones para producir tributo, limosnas y repartimientos. Esta intención se evidencia en el caso de la hacienda del pueblo de Tunkás, que se fundó para aliviar la pesada carga que representaba para los indios regidores el que se les obligara "en la antigüedad a costear la cera, incienso, jabón para el aseo de la ropa blanca de la iglesia y misas de festividades, quedando por esta razón empeñados los más hasta cantidad de ochenta pesos en cada un año". El cabildo decidió entonces juntar a los indios ancianos y principales "y hécholes presente esta carga tan pesada y gravosa",

${ }^{19}$ AGI, México 3066, Certificación del doctrinero de Mocochá fray Lázaro Calderón, Mocochá a 27 de junio de 1782 , ff. $81 \mathrm{r}-82 \mathrm{v}$.

${ }^{20}$ AGI, México 3066, Declaración del teniente de cacique del pueblo de Baca sobre su hacienda de cofradía del pueblo, Dzidzantún a 2 de septiembre de 1782 , ff. $768 \mathrm{r}-773 \mathrm{r}$. acordaron que cada individuo del pueblo diese algunos reales para comprar ganado y poblar una hacienda, con cuyos productos se afrontasen esos gastos. Decidieron retener el dinero de un repartimiento de cera y patíes que el pueblo produjo sin recibir paga alguna. ${ }^{21}$ Así, el esfuerzo colectivo para la fundación de haciendas de cofradía no era la simple suma de aportaciones individuales sino una estrategia dirigida por la élite, pues el repartimiento de géneros se basaba en contratos forzosos cuya realización era responsabilidad de las autoridades indígenas. Destinar los salarios que los indios debían percibir por su contribución al repartimiento oficial significa en realidad que se trata de aportaciones en trabajo para el logro común de establecer las estancias de cofradía. ${ }^{22}$

En la fundación y administración de las haciendas se encuentra siempre la presencia rectora del cabildo, ${ }^{23}$ aun cuando el primer fundador era un individuo y declaraba su intención de dedicar su donación al culto. ${ }^{24}$ Incluso en aquellos casos en los que la fundación no fue promovida por el cabildo, esta instancia regía su administración. ${ }^{25}$ Los escritos de donaciones de individuos

${ }^{21}$ AGI, México 3066, Declaración del alcalde de Tunkax, Valladolid a 10 de julio de 1782 , ff. $835 \mathrm{v}-838 \mathrm{v}$. Otro caso donde el origen se fincó en el repartimiento es la hacienda de las cofradías de Peto, pues en el siglo anterior (XVII) el común hizo donación "del estipendio del repartimiento" y se compraron reses, caballos y colmenas. AGI, México 3066, Declaraciones de indios de Peto, Tixcacal a 10 de julio de 1782, ff. 87or$873 \mathrm{v}$.

22 Esta aportación laboral colectiva dirigida por la élite no se limitaba al repartimiento, pues en la hacienda de Bolompoxché las primeras 15 cabezas de ganado se obtuvieron a cambio de maderas "que cortó el común de su pueblo”. AGI, México 3066, Declaración del cacique de Bolompoxché, Samahil a 22 de agosto de 1782, ff. 267r-269v.

${ }^{23}$ De la misma manera, muchas de las cofradías indígenas de Guerrero estaban dirigidas por el "común" o gobierno del pueblo que vigilaba su funcionamiento, el nombramiento de encargados y prestaba tierras de propiedad comunal. D. Dehouve, Entre el caimán y el jaguar..., 1994, pp. 130-131.

${ }^{24}$ Por ejemplo, en el caso de la estancia de Nolo la primera vaca la dio Mateo Huh para los gastos de la fiesta del Cristo, pero aclaró que "es para que cuiden mi señor cacique y mis señores justicias, regidores, escribano". AGI, México 3066, Instrumento en maya de donación, Nolo a 8 de septiembre de 1752, ff. 685r-686r. Traducción libre. Años después, un hijo del primer donador era cacique del pueblo.

${ }^{25}$ Ese fue el caso de la estancia de Bolonchén Cauich, fundada por los sirvientes de la iglesia, pero diputados nombrados por el cabildo corrían a cargo de su administración. AGI, México 3066, Declaración de Lázaro Batum teniente de Bolonchén Cauich, Campeche a 22 de julio de 1782 , ff. $464 \mathrm{v}-468 \mathrm{v}$. 
indígenas para fundar las haciendas hacen explícita también la clara intención de contribuir a reforzar la capacidad del pueblo para afrontar sus obligaciones. Así por ejemplo, en 1709 dos principales entregaron cuatro reses destinadas al culto a San Pedro del pueblo de Cholul "para que venda uno mi señor justicia y se compre cera, tinta y otra cosa que se necesite para el trabajo en el pueblo y se venda para ayudar al pueblo". 26 En el mismo sentido el cacique de Bokobá, don Marcos Uitz, declaró que en el origen de su estancia de cofradía "la mente de los primeros fundadores no fue para que el ordinario eclesiástico tuviera conocimiento de ella en ningún tiempo sino que la fundación fue para que tuviese el común de su pueblo fondo con qué comprar cera, pólvora, vestido de la Señora y limosna para las misas".27

Un caso concreto puede ilustrar este origen de las haciendas de cofradía vinculado en primera instancia a las necesidades del pueblo y no al culto. Se trata de la estancia del pueblo de Tixkochoh. En mayo de 1697, Andrés Pech donó una vaca con su cría para que el pueblo los mantuviese "en sus linderos". Poco después, en abril de comunidad". Las dos donaciones parecen haberse hecho a cambio de pedazos de tierra. Al mismo tiempo, en febrero de 1698, se sacó dinero del fondo comunal para comprar dos ganados más "para la comunidad, para que atiendan los ancianos, que lo vean y no digan que no saben de las entradas o donde va su dinero, para que se puedan ayudar". Pero no es hasta el año de 1713 cuando se menciona a la estancia, llamada Chulul, conformada como cofradía y se consigna haber enterrado con limosnas a los donadores originales Pech y Canché. 28 Otras declaraciones corroboraron que en este caso el culto fue un fin añadido al establecimiento de la estancia. ${ }^{29}$

${ }^{26}$ AGI, México 3066, Instrumento en maya de donación de ganado para la estancia de cofradía, Cholul a 5 de ? de 1709, ff. 803r-v. Trad. libre.

27 AGI, México 3066, Declaración del cacique de Bokobá don Marcos Uitz, Dzidzantún a 24 de julio de 1782 ,ff. 599v-603r.

28 AGI, México 3066, Documentos en maya de la estancia de cofradia, Tixkochoh a 2 de abril de 1713, 20 de mayo de 1697, 20 de febrero de 1698,16 de abril de 1699 y 9 de mayo de 1780, ff, 641r-643v. Trad. libre. 29 Otro testigo dijo no saber "que en su fundación se tuviese por objeto el culto a ningún santo y que posteriormente — no sabe con qué

\section{LA TIERRA EN LAS HACIENDAS DE COFRADÍA}

En el caso yucateco el examen de la tenencia de la tierra en época prehispánica y colonial recibió poca atención en el pasado y se popularizó la idea del predominio casi absoluto de la propiedad comunal. Así por ejemplo, N. Farriss concibió a la familia extensa como base de la sociedad maya y que en su interior la tierra "era claramente colectiva" sin derecho a posesión individual. ${ }^{30}$ Sergio Quezada planteó que los mayas sólo conocieron la propiedad comunal debido a su concepción del Universo y a que el acceso a la tierra era prerrogativa de las deidades. ${ }^{31} \mathrm{Re}$ sulta interesante el planteamiento de Alejandra García Quintanilla sobre la concepción cosmogónica de monte o k'ax en la relación de los mayas con la naturaleza pero no analiza la tenencia de la tierra y la propiedad por considerar que se trata de un concepto "occidental".32 Sin embargo, algunos trabajos han postulado la complejidad del sistema de tenencia de la tierra entre los mayas. Alfonso Villa Rojas propuso la existencia de seis formas de tenencia que se pueden sintetizar en: 1) tierras del Estado, 2) tierras de los pueblos que conformaban una provincia, 3) tierras de la parcialidad, que Villa Rojas llama también del calpulli - y agrega que no se ha logrado definir en forma precisa el tipo de dominio ejercido sobre ellas-, 4) tierras del linaje, que serían subdivisiones dentro de cada parcialidad y que correspondían a grupos familiares o linajes patrilineales, 5) tierras de la nobleza, es

motivo - se introdujo el de San José a cuya honra se celebraba ahora tiempo una misa", y agregó que "aunque eran bienes del común del pueblo según su fundación, pero después resultaba el culto del santo introducido con el sobrante de sus gastos y porque como era misa del santo patrón del pueblo [y] la había de pagar del fondo de su común, se ahorraba este gasto gastándolo el fondo" de la hacienda. AGI, México 3066, Declaración del teniente de Tixkochoh Nicolás Chuc, Dzidzantún a 29 de julio de 1782 , ff. 637r-640v. El regidor Pedro Chuc y un principal, Pedro Cen, declararon en los mismos términos. Véase AGI, México 3066, Declaraciones de Pedro Cen principal de Tixkochoh $y$ del regidor Pedro Chuc, Dzidzantún a 29 de julio de 1782, ff. $644 \mathrm{r}-$ $651 \mathrm{r}$.

${ }^{30}$ N. M. Farriss, La sociedad maya bajo el dominio colonial..., 1992, pp. 215-223. Véase p. 217.

31 S. Quezada, “El linaje Xiu”, 1999, pp. 115-116.

32 A. García Quintanilla, "El dilema de Ah Kimsah k'ax, 'el que mata al monte': significados del monte entre los mayas milperos de Yucatán”, 2000, pp. 282-285. 
decir, de señorío o de los linajes reinantes; y por último, 6) tierras de los particulares, conseguidas mediante el esfuerzo personal o la inversión de capital. ${ }^{33}$ Ralph L. Roys parece inclinarse también por la complejidad en la tenencia al señalar que el acceso a la tierra obligaba a pagar tributo al señor local y que se registran señores propietarios de tierra en los primeros años de la Colonia. ${ }^{34}$ Más recientemente, Robert Patch y Mattew Restall hacen hincapié en la tierra de linaje o patrimonial. ${ }^{35}$

En otro trabajo hemos planteado la existencia de una tenencia de la tierra que se contrapone a la idea generalizada de la predominancia casi absoluta de la propiedad comunal entre los mayas de Yucatán. Con base en documentos de archivos destacamos la presencia, junto con las tierras comunales, de las corporativas y de las privadas. Por comunales entendimos la tierra de jurisdicción de los pueblos, así como aquella que permanecía baldía, sin propietario y que se podía emplear para las labranzas de subsistencia de los macehuales, para la caza y la recolección, entre otros usos. En la categoría de tierras corporativas incluimos aquellas que se empleaban para hacer las milpas anuales de la comunidad para los gastos del cabildo y la milpa para el sustento del cacique, así como las tieras que por mecanismos de venta, donación y préstamo pasaron a manos de las cofradías. Por último, en calidad de privadas apuntamos las posesiones que, de acuerdo con los documentos, pertenecían a familias o linajes y también las que, inequívocamente, eran de carácter meramente individual. En ambos casos estas propiedades privadas se podían heredar, vender, arrendar y enajenar y estaban sancionadas por la costumbre y protegidas por el derecho. ${ }^{36}$

En un trabajo reciente, Pedro Bracamonte y Sosa abordó los dos ámbitos de la territorialidad de las repúblicas indígenas en el Yucatán colonial. El primero hace refe-

33 A. Villa Rojas, "La tenencia de la tierra entre los mayas de la antigüedad”, 1985, pp. 24-43.

${ }^{34}$ R. L. Roys, The Indian Background of Colonial Yucatan, 1943, pp. 3637.

${ }^{35}$ M. Restall, The Maya World..., 1997, pp. 206-211, y R. W. Patch, Maya and Spaniards in Yucatan..., 1993, pp. 67-81.

36 Bracamonte y Solís, Espacios mayas de autonomía..., 1999, pp. 151175 .

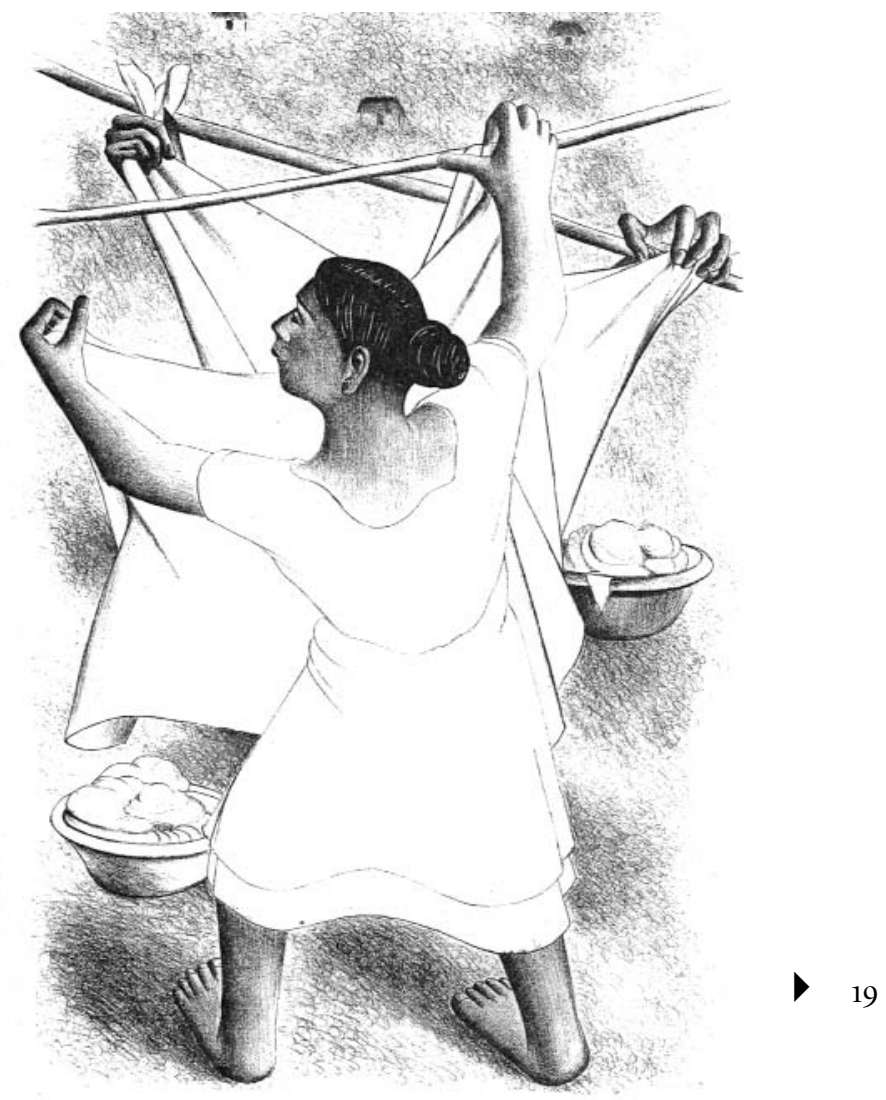

Francisco Dosamantes, Tender la ropa, 1946.

rencia al concepto de jurisdicción, esto es, al espacio político-territorial administrado por caciques y cabildos, instancias en las que recaía el control de ese recurso con base en el dominio eminente que el monarca español concedió a los indígenas americanos. Señala que la política de reducciones estipuló la necesidad de que fueran delimitados los contornos de los pueblos para evitar conflictos, ya que por derecho de conquista toda la tierra pasó a formar parte del patrimonio real y el monarca español concedió a los pueblos indígenas el dominio de ese recurso para la subsistencia de sus habitantes. ${ }^{37}$ Describe

\footnotetext{
${ }^{37}$ Bracamonte y Sosa retoma un planteamiento de René García Castro sobre la zona otomiana y sugiere que la configuración territorial y la jurisdicción política que se puede entrever en los tratados yucatecos de tierras abarca: a) la redefinición del ámbito espacial de los pueblos,
} 


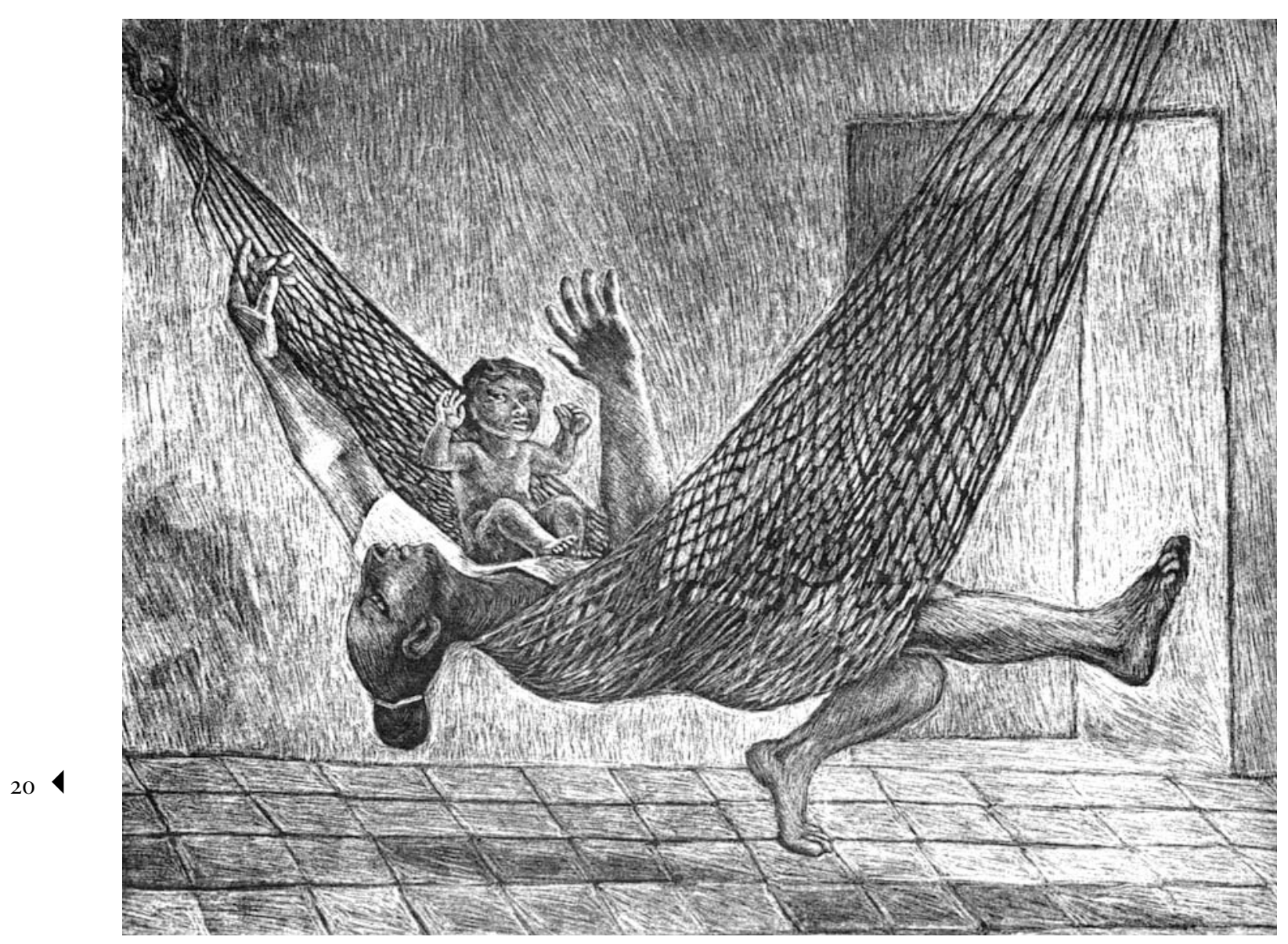

Alfredo Zalce, Hamaca, 1945.

la formación de ese ámbito haciéndolo derivar de las reducciones impulsadas por los religiosos pero, sobre todo, de una serie de tratados de linderos efectuados por las propias autoridades indígenas consignados en convenios escritos y mapas que tuvieron valor legal a lo largo de la Colonia. Entre los más importantes se deben destacar: el acuerdo de tierras entre las provincias de Sotuta y Tutul Xiu en 1545, la demarcación de las tierras del pueblo de

b) la confirmación del dominio eminente sobre los recursos básicos como son el agua y la tierra, c) la reubicación de los asentamientos dispersos y d) la configuración de centros y límites más precisos dentro de los pueblos. Véase R. García Castro, Indios, territorio y poder en la provincia matlazinca..., 1999, p. 126.
Yaxkukul, la convención de Maní de 1567, los acuerdos de tierras de la provincia de Ah Canul consignados en el Códice de Calkiní, un acuerdo de uso común de un extenso territorio entre los pueblos de Umán, Abalá, Bolonpoxché y Chocholá y las parcialidades de Dzibikal y Dzibikak y una cesión de tierras de los indios de Caucel a los del barrio de Santa Catarina de Mérida. Los tratados compaginaron tanto los antiguos límites entre provincias mayas como los perímetros de cada una de las repúblicas recién creadas por la colonización. ${ }^{38}$

${ }^{38}$ Los tratados que cita Bracamonte son: Documento $n .1$ del deslinde de tierras en Yaxkukul, Yuc., Alfredo Barrera Vásquez (editor), INAH, col. Científica, México, 1984; Ralph L. Roys, The Indian..., 1943, pp. 175- 
El segundo ámbito que aborda Bracamonte es precisamente el de la tenencia en el marco de esa jurisdicción y se enfoca al examen de las tierras comunales y privadas. ${ }^{39}$ Destaca, en el primer caso, el control ejercido por las autoridades locales sobre la tierra pública; su poder de decisión incluso para enajenarla en cantidades importantes. Pero más significativo es su análisis de las tierras de los ch'ibales o patrimonial que concibe como la forma de tenencia más arraigada entre los mayas, posiblemente desde la época prehispánica. En el periodo colonial este tipo de tenencia, vinculada a hombres de un mismo patronímico en el interior de un pueblo, tuvo su origen, al parecer, en la tierra que pertenecía a los asentamientos menores que fueron deshabitados y su población congregada en las cabeceras. La posesión quedó sancionada en la costumbre y también se le asignó valor legal en testamentos, certificaciones y en el reconocimiento incluso de las autoridades españolas. Este tipo de propiedad se reprodujo a lo largo de la Colonia pero existen datos que indican una secular tendencia hacia la fragmentación e individualización, seguramente por la influencia del mercado de la tierra que se fue abriendo paso desde mediados del siglo XVII en la península yucateca y que impulsaría el desarrollo de la propiedad particular y de las estancias ganaderas. ${ }^{40}$ De todas formas, la tenencia de la tierra privada y asociada a los chibales se puede ubicar todavía con mucha fuerza durante la segunda mitad del siglo XIX, al igual que la propiedad individual. ${ }^{41}$

194, 190, 192-194 y The Titles of Ebtun, Carnegie Institution of Washington, Washington, D. C., 1939; Pedro Bracamonte y Sosa y Gabriela Solís, Espacios mayas..., 1996, p. 141; Tsubasa Okoshi, "Los Canules: análisis etnohistórico del Códice de Calkinî", 1992, pp. 107-146; AGN, Tierras, vol. 1419, exp. 2, Trasunto de un convenio de uso común de tierras entre Umán, Chocholá, Abalá y las parcialidades de Dzibikal y Dzibikak, Abalá, 15 de marzo de 1815, f. 56r-v; AGN, Tierras, vol. 833, exp. 2, Trasunto de cesión de tierras del común de Caucel a indios del barrio de Santa Catarina, Caucel a 23 de mayo de 1657, ff. 145r-147v; Michel Antochiw, Historia cartográfica de la península de Yucatán, Gobierno del estado de Campeche-Grupo Tribasa, México, 1994, p. 36. Véase P. Bracamonte y Sosa, "Los mayas y la tierra. La propiedad indígena en el Yucatán colonial", 2002, pp. 44-77.

${ }^{39} \mathrm{Ibid}, \mathrm{pp} .104-120$.

${ }^{40}$ Ibid, pp. 120-157 y 180-194.

${ }^{41}$ A. Güémez Pineda, "Los mayas ante la emergencia del municipio y la privatización territorial”, 2001, pp. 367-389.
Queda claro que los nuevos estudios sobre tenencia de la tierra entre los mayas yucatecos cuestionan de raíz el postulado de la hegemonía de la tenencia colectiva, un planteamiento que se fundamenta en el supuesto de que las divisiones políticas consideradas como básicas en la organización social, llamadas en maya cuchteeles, son análogas a los calpullis estudiados en el centro de México. Así, el cuchteel se ha concebido como una unidad político-territorial formada por varias familias extensas que tienen unidad residencial de carácter patrilocal que se puede identificar por un topónimo y en donde la propiedad de la tierra sería colectiva y las familias tendrían acceso a ella indistintamente de acuerdo con sus requerimientos. En esta visión de la sociedad maya el cuchteel sería, también, una unidad de trabajo con funciones administrativas y probablemente de carácter militar. Se establece la posibilidad de que el gobierno local hubiera funcionado colectivamente, es decir "que entre los jefes de las familias resolvieran las cuestiones económicas, políticas y administrativas" 42 Pero esta visión no ha resistido una crítica sustentada en una acuciosa búsqueda de información documental, en la que reiteradamente surge la propiedad patrimonial e individual desde los años inmediatos a la conquista hasta mediados del siglo XIX. El supuesto de la tierra colectiva como base de la sociedad maya se ha desprendido entonces de una comparación del cuchteel con una antigua y superada noción del calpulli concebida como entidad igualitaria, como lo plantearan en la década de 1870 Morgan y Bandelier, para quienes no existió Estado ni sociedad política en el México antiguo. ${ }^{43}$ Ya Luis Reyes García ha demostrado la complejidad del concepto de calpulli que no puede ser asociado exclusivamente a la posesión comunal de la tierra, ${ }^{44}$ una visión que se desprende de la obra de Alonso

\footnotetext{
42 S. Quezada, Pueblos y caciques, pp. 38-42.

43 Véase L. Reyes García, "El término calpulli en documentos del siglo XVI", 1996, p. 21

44 Este autor plantea los diversos significados posibles del término calpulli para el siglo XVI entre los pueblos de habla náhuatl y de la ciudad de México, que sintetiza en: a) territorio, lugar de residencia (barrio estancia, pago) o los grupos de trabajadores (cuadrillas) de estos sitios; b) templo o fieles de un mismo templo (collación); c) grupo étnico (parcialidad); d) casa de mayorzago (tecpan) casa grande, sala. L. Reyes García, "El término calpulli...", pp. 35-46, especialmente p. 44.
} 
de Zorita y que es fruto de la militancia "pro indígena" de ese autor y de su crítica a la explotación colonial. ${ }^{45}$

Las referencias a la tierra en las haciendas de cofradías indígenas de Yucatán contenidas en las declaraciones de los propios indígenas coinciden con la propuesta de un sistema de tenencia que combina tanto la posesión comunal o de jurisdicción con la propiedad patrimonial o de los ch'ibales y con la tenencia particular. Estas haciendas representaron una estrategia que reforzó la propiedad corporativa al fincarse en tierras de comunidad, igualmente corporativas, pero también en tierras "prestadas" y en donaciones de propiedad privada, tanto de particulares como de familias o patrimoniales. Tanto el común como los indios particulares dieron la tierra en calidad de préstamo para prevenir una posible enajenación.

La información sobre la tenencia de la tierra en 70 haciendas de cofradía consignadas en las declaraciones indica una precaria y a la vez compleja situación con respecto a la propiedad. Los declarantes señalaron que 40 haciendas carecían de este recurso pues 14 no tenían tierra, 9 la tenían prestada y 17 de las haciendas ocupaban
Esta información coincide en términos generales con la que ofrecieron las certificaciones de religiosos sobre 40 cofradías indígenas. Consignaron que 15 de ellas no tenían tierras propias y que diez usufructuaban tierras donadas; en un caso se consigna la existencia de tierras prestadas, en tanto que ocho haciendas habían comprado la tierra para sus fondos y en seis casos no se especifica la propiedad. En la siguiente gráfica se presenta esta situación de la tenencia de la tierra en las haciendas de cofradías indígenas:

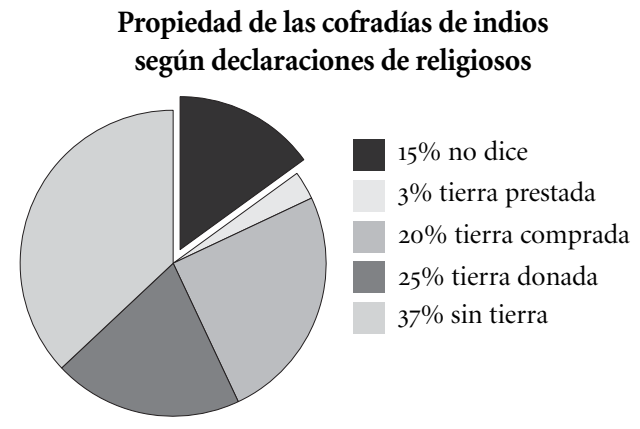

Se ha planteado que el análisis de las tierras patrimoniales o de familias es determinante para entender la estratificación, los vínculos de sujeción y el acceso restringido al poder político entre los mayas de Yucatán. ${ }^{46}$ Las referencias a este tipo de propiedad de la tierra en la documentación consultada son las siguientes: Pedro y Marcos Eb dieron el primer ganado de la hacienda Dzonot de Cacalchén y “también las tierras por ser propias”. Se trataba de 200 mecates. ${ }^{47}$ El segundo caso es la donación de un sitio y un solar en el camino de Conkal que hicieron en 1718 Francisco, Cristóbal, Gregorio y Nicolás Cen, principales del pueblo de Chicxulub para fundar la hacienda Santa

\footnotetext{
46 Se debe destacar la importancia de las tierras llamadas patrimoniales por la relevancia que la familia extensa tenía en la base de la organización social de los mayas, tanto en la época prehispánica como colonial. Un planteamiento reciente sobre la complejidad de los linajes patrilineales mayas y su segmentación puede consultarse en P. Peniche, "La diáspora indígena a las estancias yucatecas del siglo XVIII", 2002, pp. 29-35.

47 AGI, México 3066, Declaraciones de indios de Cacalchén, Dzidzantún a 26 de julio de 1782, ff. 613r-624r.
} 
María. ${ }^{48}$ Posiblemente hubiese un tercer caso de tierra patrimonial, pues en el pueblo de Sitpach, donde varios individuos de diversos patronímicos donaron la tierra, uno de los testigos afirmó que los donantes fueron los Ekes (del apelativo Ek) del pueblo de Nolo junto con principales de Sitpach, pues la estancia estaba entre los montes de ambos pueblos. ${ }^{49}$ La certificación del doctrinero de Teabo consigna un caso más: el de la estancia de la cofradía del Milagro del pueblo de Pencuyut cuya tierra la recibió en donación de Pascual, Gaspar e Ignacio Chab. ${ }^{50}$

$\mathrm{Al}$ parecer, las autoridades eclesiásticas estaban conscientes del problema que podría representar el que la propiedad de la tierra en la que estaban fincadas las haciendas fuese de los indios porque intentaron fomentar la compra de los terrenos que ocupaban para asegurarse que en ningún tiempo fuesen reclamados por sus propietarios. Esta intención se concretó, por ejemplo, en el pueblo de Teya donde los indios donaron ganado a la cofradía pero éste se puso en tierras pertenecientes al común. Por esta razón, a principios del siglo XVIII el obispo Reyes mandó se diesen a la comunidad ocho toros pertenecientes a la cofradía cuyo valor estimaba ser el de las tierras que ocupaba "para que en ningún tiempo alegasen derecho". 51 También en el caso de la hacienda del pueblo de Chocholá, su cura, don Juan Manuel Bautista Rosel dio las primeras seis novillonas "a cambio de tres cuadros [de tierra] que tenían pertenecientes al común".52 De esa manera el cura contribuyó con ganado a los fondos de la cofradía, pero al mismo tiempo aseguró la propiedad de la tierra para que el común no la reclamase. En

${ }^{48}$ La relación entre fundadores y donadores con la estructura política de cargos es evidente porque Francisco Cen era alcalde y Nicolás Cen era escribano del cabildo. AGI, México 3066, Instrumento en maya de donación de sitio para la cofradía, Chicxulub a 19 de febrero de $1718, \mathrm{f}$. 748r. Traducción libre.

49 AGI, México 3066, Declaración de un principal de Sitpach, Dzidzantún a 23 de agosto de 1782, ff. 764r-768r.

50 AGI, México 3066, Certificación del doctrinero de Teabo fray Pedro Marín, Teabo a 3 de julio de 1782, ff. 66r-69v.

${ }^{51}$ Esta información está contenida en AGI, México 3066, Certificación del doctrinero de Teya fray Josef Pérez, Teya a 25 de junio de 1782, ff. $76 \mathrm{v}-78 \mathrm{r}$. Las certificaciones que redactaron los doctrineros a menudo incluyen, como en este caso, datos previos que se consideraron relevantes.

52 AGI, México 3066, Declaración del cacique de Chocholá, Umán a 29 de agosto de 1782, ff. 299r-303r. otras palabras, se trató de una donación de ganado condicionada a la cesión de la tierra por parte del pueblo.

Un único caso nos señala la fundación de haciendas de cofradía para mantener la propiedad y jurisdicción de tierra ante los movimientos poblacionales de congregación. ${ }^{53} \mathrm{Al}$ parecer la cofradía Hilacam, a cuatro leguas de Calkiní, su cabecera, se fundó por haber sido pueblo de visita, "y habiéndoles obligado a los indios a dejar aquello y poblarse en esta dicha cabecera, cuando lo ejecutaron determinaron que aquel paraje quedase para estancia de Nuestra Señora [...] y los que voluntariamente quisieron quedarse para el cuidado de lo susodicho se dedicaban en labrar milpas y cultivarlas para ir aumentando la estancia y bienes". Según su doctrinero, los indios se sentían agraviados por el remate porque ellos no habían donado la tierra e incluso el uso de los pozos de la estancia estaba estrictamente condicionado a la "precisa obligación de que sólo sirvan para el ganado que fuese de las imágenes de sus advocaciones”, además de que ya no podrían milpar en sus mismas tierras pues "aunque se venda la planta de la estancia y no las tierras o montes, el que la compre ha de usar para sus labranzas de los montes circunvecinos como si fuesen propios, impidiendo que los indios — que son legítimos dueños — puedan labrarlos y para conseguirlo se ha de seguir disturbio y queja a los superiores".54

Un caso nos puede ilustrar sobre el origen de la propiedad de la tierra de las haciendas de cofradía a partir de tierras indígenas, comunes y particulares, y sobre el tránsito de propiedad a manos españolas. Se trata de la cofradía de Nuestra Señora del pueblo de Tekax. En 1640 don Cristóbal y don Juan Catzim, este último gobernador del pueblo, obtuvieron permiso para mantener un colmenar en una sabana llamada Tahnab a una legua del pueblo,

\footnotetext{
${ }^{53}$ El resguardo del recurso de la tierra a través de la fundación de una cofradía fue posible porque estas asociaciones, a través del culto al santo patrono, ayudaban "a reforzar la fidelidad del indígena a su república original”, incluso en el caso de migraciones de largo plazo "cohesionando a sus integrantes independientemente de su lugar de residencia”. P. Bracamonte y Sosa, La memoria enclaustrada..., 1994, p. 52 .

${ }^{54}$ AGI, México 3066, Certificación del doctrinero de Calquiní fray Josef Ignacio Perdomo, Calquiní a 23 de junio de 1782, ff. 88r-91v.
} 
en tierras realengas. En ese sitio pastaban los caballos de la comunidad, "la cual pone persona que los guarde".55 El permiso fue confirmado. ${ }^{56}$ En 1649 don Juan Catzim cedió el sitio con corral, casa y pozo a medio abrir a la cofradía del pueblo por una deuda de 50 pesos que tenía con la asociación. Según el escrito de cesión, el sitio se lo había dado su consuegro Francisco Sulú, contaba con las licencias necesarias y lo daba "para que esté en él el ganado de dicha cofradía”. Así saldaba su deuda y por tanto "él ni sus hijos ni herederos no lo pedirán ni pondrán pleito ninguno".57

Ocho años después, en 1657, la cofradía vendió el sitio a Diego Pérez de Arriaga, vecino de Mérida, en sólo 40 pesos, por estar "yermo y despoblado por haberse consumido el ganado que en él tenía de Nuestra Señora”. El patrón y mayordomos pidieron previamente permiso para la transacción a su padre guardián así como "a todos los indios viejos de este dicho pueblo, y dijeron se venda". ${ }^{58}$ Diego Pérez consolidó la propiedad al obtener merced y licencia del gobernador provincial para poblar el sitio con ganado mayor. ${ }^{59}$ Sin embargo, en 1659 el defensor general de los naturales contradijo la venta con diversos argumentos; ${ }^{60}$ negó la validez de las diligencias por la poca confiabilidad de las declaraciones de los indios sobre la ausencia del daño en el establecimiento

${ }^{55}$ AGI, México, 245, N.7/2/3r-v, Acordada y auto para que Cristóbal y Huan Catzim puedan tener un colmenar en el sitio Tahnab y pasten los caballos de la comunidad del pueblo de Tekax, Tekax a 11 de octubre de 1640 .

${ }^{56}$ AGI, México, 245, N.7/2/3v-4r, Auto del gobernador Enrique Dávila y Pacheco a favor de Cristóbal y Juan Catzim confirmando licencia para colmenas y caballos en el sitio Tahnab, Tekax a 16 de febrero de 1645.

${ }^{57}$ AGI, México, 245, N.7/2/11v-12r, Trasunto del escrito en maya de cesión de don Juan Catzim del sitio Tahnab a la cofradía del pueblo, Tekax a 23 de septiembre de 1649 .

${ }_{58}$ AGI, México, 245, N.7/2/11r-v, Trasunto de la escritura de venta del sitio Tahnab de la cofradía de Tekax a favor de Diego Pérez de Arriaga, Tekax a 25 de febrero de 1657.

59 AGI, México, 245, N.7/2/10r-v, Merced y licencia del gobernador Francisco de Bazán a favor de Diego Pérez de Arriaga del sitio Tahnab, Oxcutzcab a 26 de septiembre de 1657 . Esta licencia fue precedida de declaraciones de indios de los contornos de no serles de perjuicio. Véase AGI, México, 245, N.7/2/6v-9r, "Declaraciones de indios sobre la venta del sitio Tahnab de la cofradía de Tekax a favor de Diego Pérez de Arriaga, Tekax a 25 de septiembre de 1657".

${ }^{60}$ AGI, México, 245, N.7/2/13v-15r, Petición del defensor de indios contra la venta del sitio de cofradía llamado Tahnab del pueblo de Tekax, Mérida a 18 de septiembre de 1659 . de la estancia pues eran palpables los perjuicios y que si no lo representaban era por su "pusilanimidad para quejarse porque más quieren perder su trabajo que no venirse a quejar" y por tanto había "de perecer la causa del miserable indio". Solicitó revocar las diligencias "pues no ha de prevalecer la comodidad de un particular con un daño tan general". ${ }^{61}$ La determinación de Diego Pérez de establecer su estancia lo llevó a recurrir al rey en 1666 para solicitar la confirmación de la licencia proveída a su favor por el gobernador Bazán. ${ }^{62}$

La complejidad en la tenencia de la tierra que presentan las haciendas de cofradía se manifiesta en el caso de las estancias de los pueblos de Homún y Cuzamá. En los libros de la cofradía de Homún se asentó un auto que mandaba que el dinero de esa cofradía se invirtiese en ganado y se pusiese, no en su estancia Tubún sino en la estancia Chun Kanán de la cofradía del pueblo de $\mathrm{Cu}$ zamá para que al estar en unas mismas tierras el ganado de ambas cofradías se ahorrasen gastos. Sin embargo, en febrero de 1797, el cura de Homún, Luis Joaquín de Aguilar, alegó que las tierras de la estancia Chun Kanán no eran propias de la cofradía pues "a mí me pertenecen como dueño que soy de los montes de Nohdzaca, que fue de los indios Hoiles". Además, los luneros le reconocían como dueño y le daban el trabajo del día lunes de obligación. Por tanto solicitaba que el ganado y colmenas de ambas cofradías pasasen a la estancia Tubún que tenía tierras propias. ${ }^{63}$

${ }^{61}$ AGI, México, 245, N.7/2/18v-19v, Petición del defensor de los naturales contra la población del sitio Tahnab de Tekax con ganado mayor, Mérida a 20 de octubre de 1659. El protector solicitó en febrero de 1660 detener esta causa hasta que se revisaran los autos realizados con motivo de los perjuicios que ya había ocasionado la fundación de estancias a los indios en el área cercana a Mérida, pues aseguraba que las estancias que se habían establecido entre esa ciudad y los pueblos de Tixpéual, Tixcocob, Euán, Cacalchén, Tecoh, Timucuy y otros, aun cuando se hicieron las diligencias legales para corroborar que era sin perjuicio de indios, "es constante que en todos los dichos pueblos no sólo no tienen un palmo de tierra donde milpar sino que en sus casas $\mathrm{y}$ tan cabales no tienen los indios cosa segura, con que lo mismo ha de venir a ser en la Sierra si no se ataja el que se pueble estancia alguna". AGI, México, 245, N.7/2/30r-v.

${ }^{62}$ AGI, México, 245, N.7/1/1r-v, Petición al rey de Diego Pérez de Arriaga para poblar un sitio con ganado mayor y hacer vecindad en Tekax, Madrid a 4 de diciembre de 1666.

${ }^{63}$ AGEY, Archivo Notarial, Protocolos Coloniales, Libro 42, Solicitud del cura de Homún don Luis Joaquin de Aguilar para que las cofradías 
El cura presentó certificaciones de los justicias de ambos pueblos donde reconocían que él era el dueño legítimo de las tierras de Chun Kanán. Los de Cuzamá aseguraron que era verdad que esa estancia "no es de dicha cofradía ni pertenecen a la Señora las tierras", pues habían sido de los Hoiles de don Bernardino Hoil, quien a su muerte las legó a su hijo don Buenaventura, quien a su vez las heredó a sus hijos Diego y Juan Santiago Hoil. Estos últimos las dieron para poblar la estancia de la cofradía de Cuzamá con título de préstamo, pero después las vendieron al cura Aguilar, "actual poseedor y legítimo dueño de ellas". Sin embargo, reclamaron la propiedad del ganado y de las colmenas para la cofradía. Los priostes, mayordomos y escribano de la cofradía ratificaron la certificación de los justicias de Cuzamá. Lo mismo certificaron los cabilderos de Homún. ${ }^{64} \mathrm{El}$ cura intentó quedarse con el ganado y con las colmenas con el argumento de que se encontraban en sus tierras, pero el provisor eclesiástico emitió un auto concediéndole únicamente "el dominio directo de los corrales, portadas y demás construido" en la estancia. ${ }^{65}$

La importancia del agua para el establecimiento de las haciendas de cofradía se refleja en las donaciones iniciales que incluyen pozos y cenotes. En el pueblo de Dzan los principales donaron un pozo a su estancia Lumá fundada en 1709, el cabildo de Maní donó una sabana con cenote para establecer la estancia Yalná, el cacique de Dzemul, don Lucas Canul, donó la planta y el pozo para la estancia Santa María y los naturales del pueblo de Kiní donaron un pozo "de limosna" para la estancia de la cofradía de

de Homún y Cuzamá le desocupen unas tierras de su propiedad, Mérida a 11 de febrero de 1797 , ff. $25 \mathrm{r}-\mathrm{v}$.

64 AGEY, Archivo Notarial, Protocolos Coloniales, Libro 42, Certificaciones de los cabildos de las dos parcialidades de Cuzamá, de los oficiales de cofradia de ese pueblo y del cabildo de Homún sobre la propiedad de las tierras de la estancia Chun Kanán, enero de 1795, ff. 26r-27r.

65 AGEY, Archivo Notarial, Protocolos Coloniales, Libro 42, Auto del doctor don Santiago Martínez de Peralta, juez provisor y gobernador del obispado, a favor del cura don Luis Joaquín de Aguilar sobre la estancia Chun Kanán, Mérida a 23 de mayo de 1797, f. 32v.

Luis Arenal, Cabeza de mujer indigena, 1948.

San Antonio fundada en 1700. ${ }^{66}$ Las declaraciones de los mismos indios reportan la donación de varios pozos, como la de don Agustín Noh, quien dio tierras y pozo para la estancia Chulvayum del pueblo de Dzilam; Antonio Che donó el pozo ante su cacique y justicias y sólo "prestó" las tierras para la estancia Texán del pueblo de Kiní; lo mismo se refiere para la estancia Xlabón de Bokobá donde Gaspar Pat donó tierras y pozo y sólo en este último no reservó dominio. En el caso del pueblo de Tekantó, que tenía cuatro estancias de cofradía, Manuel Balam donó el pozo a la estancia Jesús; en la de Samulá, las tierras y el pozo se compraron con los productos de la estancia; en la de San Antonio — donde las tierras eran del común- el pozo lo había "prestado" un indio; y en la de Kiní, quienes habitaban la estancia decían que el pozo era de sus antepasados. En la estancia de Tixkochoh, que no tenía tierras propias, no se sabía de quién era su

${ }^{66}$ AGI, México 3066, Certificaciones de los religiosos, junio y julio de 1782 , ff. $52 \mathrm{r}-94 \mathrm{~V}$. 


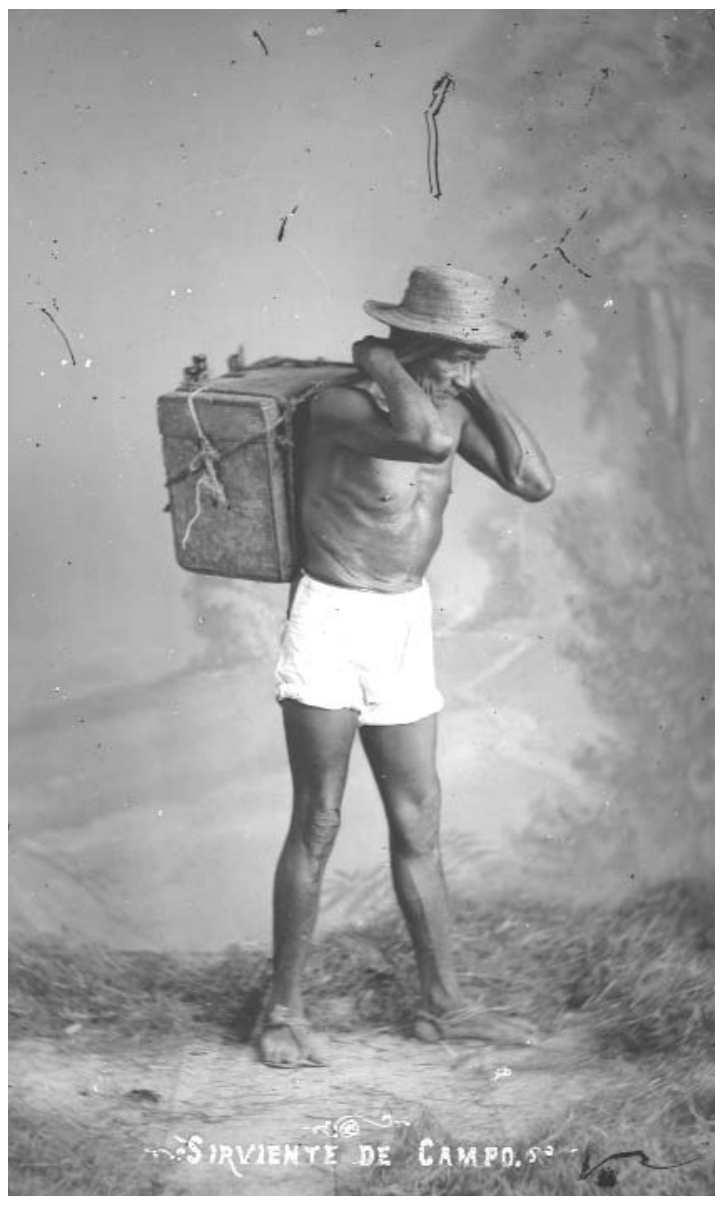

Sirviente de campo, 1880 / Fototeca Pedro Guerra, Universidad Autónoma de Yucatán.

pozo; en Baca, el cacique Juan Tep compró tierras y pozo a un indio Poot, mientras que en Mocochá, las versiones de los declarantes sobre la estancia no coinciden, pues mientras uno afirma que el pozo lo donó un indio, otro dice que lo prestaron el cacique y justicias. ${ }^{67}$

El hecho de que en la historiografía moderna se proponga que la propiedad comunal era la única forma de tenencia, $\mathrm{o}$ al menos la determinante, tiene una de sus bases en el poco interés que manifestaron las autoridades civiles

${ }^{67}$ AGI, México 3066, Diversas declaraciones de indios, año de 1782, ff. 130r-923r. y eclesiásticas por la comprensión del complejo sistema de tenencia indígena de la tierra. Esta ausencia de interés se expresa en la polémica generada por los remates de las haciendas de cofradía, donde se percibe como único modo de propiedad la comunal. El gobernador don Antonio Rivas Betancourt, al solicitar en 1781 la suspensión de los remates, argumentó que estaban fundados en tierras de los mismos indios. ${ }^{68}$ Después de realizar interrogatorios y diligencias, Rivas aseguraba que los remates representaban un despojo a la propiedad indígena pues atentaban contra la disposición real de procurar que los indios tuviesen heredades y granjerías de donde socorrerse, y esta medida, "lejos de procurarles a los indios nuevas posesiones les ha quitado las que tenían trasladándoles a ajeno señorío y defraudándoles de la esperanza de aliviar con ellas sus necesidades comunes" ${ }^{69}$ Según el gobernador, los indios esperaban la revocación de los remates para restituir

a su antiguo ser la libertad de cultivar sus tierras sin el reconocimiento de ajeno señorío y sin el dolor de ver expuestas sus labranzas y sembrados al destrozo que es indispensable se ocasione con la proximidad del ganado que se introducirá tal vez hasta los salones de sus mismas casas. ${ }^{70}$

El gobernador Rivas sostenía categóricamente que todas las haciendas de cofradía, sin excepción, se habían establecido en tierras de los pueblos y comunidades pues destinaban su producto para sus fondos.

En contraste con la defensa de la propiedad indígena enarbolada por quienes se oponían a los remates, los impulsores de la medida prefirieron obviar este asunto y se limitaron a denunciar lo que consideraban perjudicial en la relación de las haciendas con la tierra y los beneficios que acarrearían las ventas. Así, por ejemplo, los ministros del Juzgado de Indios que apoyaban los remates poco aluden a la propiedad de la tierra. Sólo lo hacen para

${ }^{68}$ AGI, México 3066, Solicitud del gobernador de Yucatán al rey para suspender el remate de haciendas de cofradía, Mérida a 6 de octubre de 1781 , ff. $16 \mathrm{v}-17 \mathrm{r}$.

${ }^{69}$ AGI, México 3066, Representación del gobernador Roberto Rivas Betancourt al rey contra el remate de haciendas de cofradía, Mérida a 30 de abril de 1783 , f. $9 v$.

${ }^{70} \mathrm{Ibid}$, ff. 10v y $11 \mathrm{r}$. 
señalar que los terrenos habían sido "entregados por los pueblos para fundaciones que se consideraban perpetuas" y que el haber conservado "el dominio y propiedad de los montes" perjudicaba a los indios que se hallaban en su demarcación al tener que dar al pueblo un día de trabajo semanal por la milpa que cultivan en su jurisdicción además de dar otro día al santo o al mayordomo por el mismo motivo. Los administradores sólo permitían unas pocas labranzas a aquellos principales "que necesitan para adelantar sus buscas" impidiendo cultivar a los demás so pretexto de perjuicios a la hacienda. Señalan varios beneficios derivados del tránsito a manos de particulares de la propiedad de las haciendas de cofradía, pues "serán los indios más dueños de sus tierras que al presente $\mathrm{o}$ - hablando con propiedad — serán en realidad dueños" ya que de aquellas que no se subastaran sólo tenían "el vano título de nombrarlas suyas" pues el dominio útil era del santo o del administrador y de algunos principales. Tras los remates los indios podrían tomar el terreno más a propósito para sus siembras y acercarse a la estancia porque su poseedor sería "mortal como ellos" y reduciría sus cultivos "a límites regulares de suerte que no los incomode"; además, las comunidades darían en arrendamiento — como era costumbre - los terrenos que antes hubieran querido tomar los administradores "que todo lo hacían propio".71

Los ministros del Juzgado de Indios intentaron rebatir el argumento de que los remates eran un despojo a la propiedad indígena al venderse el terreno donde se hallaban las haciendas que no tenían tierras propias. Pero a decir de estos funcionarios, esos terrenos habían sido entregados por los pueblos a favor de fundaciones perpetuas - como lo eran las cofradías - para construir la planta necesaria y quienes las habían administrado habían plantado o demolido, "hecho y deshecho, sin permitir a las repúblicas el uso —el más leve- ni éstas solicitándolo" ni tampoco se había oído "expresión alguna alusiva a propiedad".72

\footnotetext{
${ }^{71}$ AGI, México 3066, Representación del abogado y protector de los naturales a favor del remate de haciendas de cofradía, Mérida a 3 de junio de 1782 , ff. 22r-37v. Véase ff. 36r y 29r-31v.

72 Ibid, $36 \mathrm{r}$.
}

\section{LA ORGANIZACIÓN LABORAL}

El análisis del trabajo indígena en Yucatán ha estado vinculado al estudio de las distintas formas de exacción de fuerza laboral y se le ha puesto énfasis a la tributación por la importancia que la encomienda tuvo en esta región. ${ }^{73}$ También se ha abordado otra vía de acceso a la fuerza de trabajo indígena organizada de manera corporativa al revisar el sistema del repartimiento, entendido como contratos forzosos para la producción de géneros comercializables, especialmente mantas y cera. ${ }^{74}$ En Yucatán el servicio personal de los indios tomó la forma de mandamientos de trabajo por tandas y se destinó fundamentalmente al servicio doméstico en casas de españoles. Sin embargo, la discusión se centra en la organización autónoma del trabajo indígena, imprescindible para la generación de los recursos necesarios para cumplir con todas las cargas que pesaban sobre los pueblos, y que en Yucatán recibió el nombre de mulmeyah o trabajo colectivo. ${ }^{75}$ Los fundamentos organizativos de este tipo de trabajo contemplaban redes de relaciones fincadas tanto en la reciprocidad como en el dominio y la sujeción, donde el problema a dilucidar gira alrededor de la definición del tipo de relación determinante. Hemos optado por las relaciones derivadas de la sujeción política pues el mulme$y a h$, aunque se sustentaba en la tradición arraigada de conjugar esfuerzos mediante la ayuda recíproca, rebasaba estas relaciones "comunitarias" para canalizar fuerza laboral hacia los proyectos de la entidad política mayor bajo el control directo de la élite. ${ }^{76}$

En el caso de las haciendas de las cofradías indígenas, es posible observar la manera como distintas formas de acceso al trabajo fueron llevadas a cabo por quienes

73 Véase M. C. García Bernal, Yucatán. Población y encomienda bajo los Austrias, 1978.

${ }^{74}$ Sobre el sistema del repartimiento en Yucatán puede consultarse M. C. García Bernal, "El gobernador de Yucatán...”, 1979 e "Indios y españoles en Yucatán...”, 1992, p. 404; R. W. Patch, Maya and Spaniard in Yucatán..., 1993, pp. 89-91; G. Solís Robleda, "Bajo el signo de la compulsión...", 2000, cap II.

75 Véase Diccionario Maya Cordemex, 1980, p. 539, y Calepino de Motul, 1995, p. 533 .

${ }^{76}$ G. Solís Robleda, Bajo el signo de la compulsión..., op. cit., pp. 287288. 
administraban estas unidades productivas. La información recopilada en los pueblos de indios reporta una compleja y variada organización del trabajo que muestra que estas empresas indígenas fueron extremadamente flexibles en este renglón. Se consigna trabajo colectivo, asalariado, de comisionados por el cabildo, de servidores de iglesia y de luneros. En el marco de esta diversidad puede establecerse una periodicidad, pues se fomentaron, sobre todo en sus orígenes, con trabajo colectivo organizado por los justicias. ${ }^{77}$ Luego se registra la existencia de diputados designados por el cabildo para organizar las labores así como de quienes ocupaban cargos de cofradía, y más adelante aparecieron los vaqueros permanentes, pagados de los propios fondos de la hacienda, generalmente no más de uno o dos. Además, estaba el creciente número de indios que vivía en los linderos de las haciendas, llamados luneros, que aportaban su día de trabajo a cambio del usufructo de la tierra. Esta evolución de los sistemas de trabajo se manifiesta, por ejemplo, en la declaración del cacique de Mocochá, quien aseguró que el trabajo en la hacienda Xtolquís de la cofradía de ese pueblo lo hacían indios asalariados del mismo fondo en tiempos recientes "pero en los primeros de su fundación fue por el común del pueblo". El cacique también consignó la existencia e importancia de los luneros al afirmar que "con motivo de la dispersión de sus sirvientes en la calamidad del año del setenta" quedó arruinado su fondo. ${ }^{78}$

Los distintos mecanismos de allegarse trabajo en las haciendas de cofradía coexistieron y se recurría a ellos según las circunstancias lo requiriesen. Trabajo asalariado combinado con colectivo se refiere en el pueblo de Tixkochoh, pues su hacienda de cofradía tenía un peón pagado como vaquero, pero también "si ocurría algún trabajo extraordinario eran los del pueblo los que lo practicaban gustosos por su servicio del común y de los

${ }^{77}$ Sobre la importancia del trabajo colectivo, Islas Jiménez plantea que fue precisamente el trabajo común de los indígenas para sus cofradías y mayordomías lo que "les dio cierta cohesión y supervivencia social". C. Islas Jiménez, "Cofradías y mayordomías en la región de Tlalpujahua", 1997, p. 343.

${ }^{78}$ AGI, México 3066, Declaración del cacique de Mocochá, Dzidzantún a 2 de septiembre de 1782 , ff. 781 r- 785 r. santos". ${ }^{79}$ Lo mismo declaró el cacique de Sitilpech sobre su estancia Kancabchén. Asimismo, hay muchas referencias a las personas designadas por el cabildo para dedicarse al cuidado de estas haciendas, como el caso de la de la cofradía del pueblo de La Ceiba en Campeche, que estaba a cargo del prioste que nombraba el cabildo sin intervención de su cura. ${ }^{80}$ En el pueblo de Bokobá había 12 indios "que anualmente se señalaban para el labor de la hacienda y en las iglesias para su aseo y decencia". ${ }^{81} \mathrm{La}$ estancia Santa María del pueblo de Dzemul se inició con dos vacas que donaron cinco indias del propio pueblo, que fueron procreando "con el cuidado de seis indios que nombraron los justicias". ${ }^{2}$ Quienes ocupaban cargos en la cofradía también aportaban su trabajo para labores agrícolas, como lo afirmó un testigo del pueblo de Chemax, quien dijo que cuando su hacienda tenía ganado él acudía "como prioste y muchos individuos de su pueblo como mayordomos a construir milpas para la conservación y aumento de dicha hacienda". ${ }^{3}$

Los declarantes de todos los pueblos coinciden en señalar que quienes realizaban el trabajo de manera permanente eran los asalariados y los luneros. Por ejemplo, el patrón de la estancia Samulá del pueblo de Tekantó declaró que el trabajo de los vaqueros se pagaba y el de "los lunerarios era de obligación", pero ni uno ni otro era con coerción sino espontáneo y sin queja alguna. ${ }^{84} \mathrm{La}$ conjunción de trabajo asalariado y de luneros fue consignada también por el escribano del pueblo de Kiní, al afirmar que en la estancia de cofradía de su pueblo, nombrada Texán, "los lunerarios trabajan por la obligación de tales

\footnotetext{
${ }^{79}$ AGI, México 3066, Declaración de un principal de Tixkochoh, Dzidzantún a 29 de julio de 1782, ff. 647v-651r.

${ }^{80}$ AGI, México 3066, Declaración del cacique de La Ceiba, Campeche a 12 de julio de 1782 , f. 392 r.

${ }^{81}$ AGI, México 3066, Declaración de un alcalde de Bokobá, Dzidzantún a 24 de julio de 1782 , ff. 603r-606r.

82 AGI, México 3066, Certificación del doctrinero de Telchac fray Juan Santiago Mata, Convento de Telchac a 23 de junio de 1782, f. 711 .

${ }^{83}$ AGI, México 3066, Declaración de un prioste de Chemax, Valladolid a 9 de julio de 1782 , ff. $833 \mathrm{v}-835 \mathrm{v}$.

${ }^{84}$ AGI, México 3066, Declaración del patrón de la estancia de cofradía de Tekantó, Dzidzantún a 27 de julio de 1782, f. 637r. Lo mismo afirmó el cacique de Ekmul al declarar que dos vaqueros pagados y doce lunerarios "que tienen esa obligación" hacían el trabajo de la hacienda. AGI, México 3066, Declaración del cacique de Ekmul, Dzidzantún a 12 de agosto de 1782, ff. 661r-664v.
} 
y que si los patrones trabajaban $[\mathrm{u}]$ otros cualesquiera eran pagados del producto de la referida hacienda". 85

El análisis del trabajo de los llamados luneros es relevante toda vez que es manifestación de una muy antigua relación que se mantuvo a lo largo de la Colonia, e incluso hasta el siglo XIX, en donde el acceso a la tierra estaba condicionado a la entrega de trabajo. Se plantea entonces el problema de identificar a estas personas que vivían en las tierras de las estancias de cofradía y los vínculos que los ligaban a ellas. Robert Patch, en su análisis de las cuentas de la estancia Locá de la cofradía del pueblo de Euán, destaca el inusual registro de los nombres de los individuos que componían su fuerza laboral en un periodo largo (1745-1770). La existencia de gente del mismo apellido por varias décadas indicaría la relevancia de los lazos de parentesco y se plantea entonces como probable que tanto los vaqueros como los trabajadores agrícolas no identificados no fueran migrantes desarraigados sino más bien gente que había fincado su residencia en la tierra de la estancia de cofradía y mantenía lazos familiares. De esta manera las estancias de cofradía podrían haber sido excepcionales al estar íntimamente ligadas a las comunidades indias cercanas, lo que facilitaba a los residentes el mantener lazos con el pueblo o la comunidad local. 86

Hay que destacar que en la mayoría de las declaraciones se hace evidente la importancia del trabajo de estos luneros. Así, por ejemplo, el cacique de Cansahcab dijo que lo realizaban, "no sólo por obligación en que está constituido cualquier lunerario, como son los que andaban estas tareas, sino por desahogar su devoción". Afirmó también que la estancia Santa María Tcib fue gravemente afectada por el hambre que padeció la provincia en 1770, pero "que después de deteriorada la dicha cofradía por la necesidad sobredicha, se volvió a fomentar vendiéndose los granos que producía el trabajo de los muchos luneros que tiene", con cuyo producto se compraron diez cabezas de ganado vacuno para repoblarla. Luis Dzul, quien había ocupado varios cargos de república en Can-

${ }^{85}$ AGI, México 3066, Declaración del escribano de Kiní, Dzidzantún a 24 de julio de 1782 , ff. 596r-599r.

${ }^{86}$ Robert W. Patch, Maya and Spaniard in Yucatan, 1648-1812, 1993, p. 187. sahcab, aseguró que el trabajo realizado en la estancia no era perjudicial para los indios "porque es obligación de los luneros semejantes fatigas". 87

La obligación de los luneros de aportar un día de trabajo en retribución del usufructo del terreno que ocupaban se convirtió en un problema al discutirse la propiedad de la tierra y por tanto, el destino de los beneficios asociados a ella. Este problema lo señaló el mayordomo español de la estancia Santa María Chemay de La Ceiba al declarar que los indios del pueblo no hacían trabajo alguno en la estancia pues lo hacían los luneros avecindados en ella, sin embargo, apeló a la relación de los luneros con la tierra cuando aclaró "que en caso que dichos lunarios estén obligados a servir el lunes de gracia debería resultar en beneficio al pueblo por ser suyas las tierras y montes en que está fundada dicha estancia".88 Lo mismo declaró el cacique del propio pueblo al decir que el cura había dispuesto que los luneros trabajasen para la estancia "pero que bien visto, esta recompensa corresponde al pueblo por estar la estancia en tierras y montes de él".89

Entre los argumentos de quienes postulaban la necesidad de sacar a remate las llamadas haciendas de cofradía estaba precisamente la precaria situación de quienes laboraban en ellas. Según los ministros del Juzgado de Indios estas haciendas se habían vuelto un instrumento para vejar y oprimir a los descendientes de sus mismos fundadores al no recibir retribución alguna por los muchos días que dedicaban al aseo de la iglesia y al culto, y al no ser exentados de sus obligaciones para con el pueblo. Los encargados de manera directa del cuidado de las haciendas de cofradía recibían menos salario que aquellos ocupados en fincas particulares, que percibían ocho reales mensuales. Quienes vivían en sus tierras "dan un día de trabajo al santo y otro al pueblo", mientras que los moradores de las particulares únicamente daban el día lunes al dueño. Según estos funcionarios, en las haciendas

\footnotetext{
87 Según el prioste de la cofradía, la recuperación de la estancia fue posible gracias a "los granos que daban las labranzas que hacían los lunerarios". AGI, México 3066, Declaraciones de indios de Cansahcab, Dzidzantún a 17 de julio de 1782, ff. 530r-539r.

88 AGI, México 3066, Declaración de don Juan Ignacio Cosgaya, Campeche a 12 de julio de 1782 , f. 395 r.

${ }^{89}$ AGI, México 3066, Declaración del cacique de La Ceiba, Campeche a 12 de julio de 1782 , f. 392 r.
} 
de cofradía los indios tenían "tres amos: mayordomo, cacique y santo", y siendo el último el principal era a quien se servía menos. Sus mayordomos, al tomar la voz de los santos, lograban que todos, desde el cacique hasta el último de los indios, los mirasen "con respeto singular" y que las labranzas de la estancia se extendiesen más allá de las tierras propias, que los operarios trabajasen sin importar si habían labrado lo suyo o tenido el descanso necesario y que estuviesen dóciles al trabajo e incluso que en la paga haya alguna rebaja "pues es constante que en llegando al culto de sus imágenes todo lo ceden los indios".90

\section{CONSIDERACIONES FINALES}

La documentación disponible no ofrece información suficiente para precisar con detalle el origen de las cofradías en los pueblos de indios. Sin embargo, al revisar el establecimiento de las haciendas de cofradía queda claro que estas unidades productivas se vincularon con las asociaciones religiosas, en ocasiones con posterioridad a refleja la complejidad de su organización interna y una estratificación que dividía a sus integrantes. Si bien estas haciendas fueron sin duda empresas corporativas que reforzaban la capacidad de los pueblos para afrontar obligaciones y fueron fundadas y administradas por la élite para lograr la supervivencia colectiva, como diría N. Farriss, un análisis acucioso deja ver la complejidad de la sociedad que las produjo. Las donaciones de tierras son indicadoras de las distintas formas de tenencia más allá de la comunal. La organización laboral también refleja la flexibilidad de la corporación maya para echar mano de formas propias de canalización del trabajo, de los $l u$ neros y del trabajo colectivo, junto al trabajo asalariado. La élite seguía reforzando su posición con el control de la tierra y de la energía laboral. Sólo aflora en la documentación una imagen uniforme - que pudiera tener visos de igualitaria al soslayar las diferencias internas - cuando el pueblo presenta su causa hacia afuera para defender su empresa de la intervención de españoles y de la enajenación. Así podemos explicarnos la imagen de predominancia de la propiedad comunal percibida por las autoridades coloniales, por ejemplo. Pero esto fue una estrategia corporativa de la dirigencia al erigirse en representante de los intereses colectivos.

\section{Siglas y bibliografía}

AGEY: Archivo General del Estado de Yucatán

AGI: Archivo General de Indias, Sevilla

CAIHY: Centro de Apoyo a la Investigación Histórica de Yucatán

Assadourian, Carlos Sempat, 1994, Transiciones hacia el sistema colonial andino, El Colegio de México/Instituto de Estudios Peruanos, Perú.

Bechtloff, Dagmar, 1966, Las cofradías en Michoacán durante la época de la Colonia. La religión y su relación política y económica en una sociedad intercultural, El Colegio de Michoacán/El Colegio Mexiquense, México.

Bracamonte y Sosa, Pedro, 1994, La memoria enclaustrada. Historia indígena de Yucatán, 1750-1915, col. Historia de los pueblos indígenas de México (Teresa Rojas y Mario H. Ruz, eds.), CIESAS/INI, México.

_ 2002, Los mayas y la tierra. La propiedad indígena en el Yucatán colonial, CIESAS-Miguel Ángel Porrúa (en prensa), México. 
— y Gabriela Solís Robleda, 1996, Espacios mayas de autonomía. El pacto colonial en Yucatán, Universidad Autónoma de Yucatán, Mérida.

Calepino de Motul. Diccionario maya-español, 1995, Ramón Arrápalo Marín (ed.), 3 vols., UNAM, México.

Carrasco, Pedro, 1978, "La economía del México prehispánico", en Economía política e ideología en el México prehispánico, P. Carrasco y J. Broda (eds.), Nueva Imagen, México.

Dehouve, Danièle, 1994, Entre el caimán y el jaguar. Los pueblos indios de Guerrero, col. Historia de los pueblos indígenas de México (Teresa Rojas y Mario H. Ruz, eds.), CIESAS/INI, México.

Diccionario Maya Cordemex, 1980, Alfredo Barrera Vázquez (dir.), Ediciones Cordemex, Mérida.

Farriss, Nancy M., 1992, La sociedad maya bajo el dominio colonial. La empresa colectiva de la supervivencia, Alianza Editorial, Madrid.

García Bernal, Manuela Cristina, 1978, Yucatán. Población y encomienda bajo los Austrias, Escuela de Estudios Hispano-Americanos de Sevilla, Sevilla.

—_ 1979, "El gobernador de Yucatán Rodrigo Flores de Aldana”, separata del vol. I del Homenaje al Dr. Muro Orejón, Sevilla.

_ 1992, "Indios y españoles en Yucatán: Utopía y realidad del proyecto colonizador", en sobretiro del t. II del Congreso de historia del descubrimiento, pp. 387-427.

García Castro, René, 1999, Indios, territorio y poder en la provincia Matlazinca. La negociación del espacio político de los pueblos otomianos, siglos XVI-XVII, CIESAS-Conaculta-El Colegio Mexiquense, México.

García Quintanilla, Alejandra, 2000, "El dilema de Ah Kimsah k'ax, 'el que mata al monte': significados del monte entre los mayas milperos de Yucatán”, Mesoamérica, núm. 39, CIRMA, Guatemala.

Gibson, Charles, 1980, Los aztecas bajo el dominio español, 1519-1810, Siglo XXI Editores, México.

Güémez Pineda, Arturo, 2001, "Los mayas ante la emergencia del municipio y la privatización territorial, Yucatán, 1812-1847", tesis doctoral, Zamora, Michoacán.

Islas Jiménez, Celia, 1997, "Cofradías y mayordomías en la región de Tlalpujahua", en Historia y sociedad. Ensayos del Seminario de Historia Colonial de Michoacán, Instituto de Investigaciones Históricas de la Universidad Michoacana de San Nicolás de Hidalgo/CIESAS, México, pp. 342-364.

Kirchhoff, Paul, 1954-1955, "Land Tenure in Ancient Mexico. A Preliminary Sketch", Revista Mexicana de Estudios Antropológicos, t. XIV, primera parte, México.

Lockhart, James, 1992, The Nahuas Alter the Conquest, Stanford University Press, California.
Martínez, Hildeberto, 1984, Tepeaca en el siglo XVI. Tenencia de la tierra y organización de un señorio, CIESAS, México.

— 1994, Codiciaban la tierra. El despojo agrario en los señoríos de Tecamachalco y Quecholac (Puebla, 1520-1650), CIESAS, México.

Okoshi Harada, Tsubasa, 1992, "Los canules: análisis etnohistórico del códice de Calkiní", tesis de doctorado, UNAM, México.

Patch, Robert W., 1993, Maya and Spaniard in Yucatan, 16481812, Stanford University Press, California.

Peniche, Paola, 2002, "La diáspora indígena a las estancias yucatecas del siglo XVIII", tesis de maestría, CIESAS, México.

Quezada, Sergio, 1995, Pueblos y caciques yucatecos, 15501580, El Colegio de México, México.

—_, 1999, "El linaje Xiu”, en Dos décadas de investigación en historia económica comparada en América Latina. Homenaje a Carlos Sempat Assadourian, Margarita Menegus (coord.), El Colegio de México/CIESAS, México.

Restall, Matthew, 1997, The Maya World. Yucatec Culture and Society, 1550-1850, Stanford University Press, California.

Reyes García, Luis, 1996, "El término calpulli en documentos del siglo XVI", en Luis Reyes García, et al., Documentos nahuas de la ciudad de México del siglo XVI, CIESASAGN, México.

Rojas Rabiela, Teresa, 1987, "El trabajo de los indios en la ciudad de México: 1521-160o", en Susana Glantz (ed.), La heterodoxia recuperada. En torno a Ángel Palerm, FCE, México, pp. 171-201.

Roys, Ralph L., 1943, The Indian Background of Colonial Yucatan, Publication 548, Carnegie Institution of Washington, Washington.

Sherman, William L., 1985, El trabajo forzoso en América Central en el siglo XVI, Seminario de Integración Social Guatemalteca, Guatemala.

Solís Robleda, Gabriela, 2000, "Bajo el signo de la compulsión. El trabajo forzoso indígena en el sistema colonial yucateco, 1540-1730", tesis doctoral, Facultad de Filosofía y Letras, UNAM, México.

Stern, Steve J., 1993, Peru's Indian Peoples and the Challenge of Spanish Conquest. Huamanga to 1640, The University of Wisconsin Press.

Villa Rojas, Alfonso, 1985, "La tenencia de la tierra entre los mayas de la antigüedad", en Estudios Etnológicos. Los mayas, UNAM, México.

Wolf, Eric, 1957, "Closed Corporate Peasant Communities in Mesoamerica and Central Java", Southwestern Journal of Anthropology, vol. 13, núm. 1.

_ 1986, "The vicissitudes of the close corporate peasant community”, American Ethnologist, núm. 13. 